\title{
National Negro Organizations and Their Publications*
}

TCREASINGLY within recent years the 1 factual study of Negro life and history in the United States has engaged the attention both of research workers and of interested laymen. To such persons, source materials which afford insight into the group life and thinking of Negro Americans are of obvious concern and importance.

The present article is the result of an investigation, made in 1941, which undertook to identify and describe the types of national Negro organizations then existing in the United States, and to evaluate the publications issued by these bodies in the light of their potential usefulness as source materials for the study of Negro life and history. A further aim of the study was to find out to what extent libraries with large special collections of materials by and about the Negro, which would seem to be the logical places of deposit for these publications, were collecting these publications. The study included a list of organizations and a guide to their publications.

The basic assumptions underlying the study were that these organizations came into being, not by chance, but as the result of certain felt social needs and problems, and thus that the publications of these bodies might well reflect not only these needs and problems, but also the different approaches toward meeting and solving them now in operation among organized groups of Negroes in the United States.

The term "national Negro organiza-

* Based on a master's thesis prepared at the School of Library Service, Columbia University, 1941. tions" was necessarily difficult of precise definition, but two general criteria for inclusion under it were applied. First, only organizations were included whose purposes were concerned primarily with Negro life in the United States or some aspect of it, whether or not their memberships were confined to Negroes or included persons belonging to other racial groups. Secondly, organizations having such purposes were included under the meaning of the term "national" whose structure has been that of a central body with geographically scattered auxiliary units working for the same major aims as that of the parent body and contributing to the funds of the general treasury of the latter. Since the focus of the study was the evaluation of a body of potential library materials, a third criterion for inclusion was also applied, namely, the extent to which the organizations had issued publications. Bodies which investigation showed had no publications, or virtually none, were omitted. Finally, the effort was not made to include all national Negro organizations, but rather to give consideration to as many of the existing types as could be covered in the time available.

The method followed was primarily historical. The chief sources of data were the publications and records of the individual organizations, supplemented by biographical material on persons connected with the various organizations, newspapers and magazines, court reports, and general and local histories. The procedure used was as follows: lists of organizations and 
their publications were begun by consulting the Negro Year Book, 1937-38, Work's Bibliography of the Negro in Africa and America, the List of Negro Newspapers and Periodicals compiled by the United States Bureau of the Census, the Union List of Serials, the Social Work Year Book, the Handbook of American Trade-Unions, and other reference works. These lists were compared with the catalogs of the Schomburg Collection and the reference division of the New York Public Library, in order that any organizations or publications not included could be added and their holdings checked and publications examined. Similarly, visits were made to as many as possible of the headquarters of the organizations, and to the Fisk University Library, the Moorland Foundation of the Howard University Library, the Library of Congress, the Rand School Library, the Union Theological Seminary in New York, and the Teachers College Library of Columbia University. Consultation either by correspondence or in person with officials of the organizations and with outstanding specialists on Negro life and history took place as the study proceeded.

\section{Findings}

Six major types of organizations were distinguished: churches, fraternal organizations, "general" organizations, labor unions, educational associations, and organizations devoted to research and publication. Each type was found to be so distinct both as to purposes and publications that it was deemed best to discuss each separately. This procedure is likewise here followed.

(I) Churches. The church is not only the oldest but also the largest and wealthiest of the Negro's organizations. The Negro adult church membership (persons I3 years of age and over) reported by the United States census of religious bodies in 1936 totaled $5,660,6$ I 8 , representing 46 per cent of the entire Negro population, while the value of 38,303 Negro church edifices reported in the same year was $\$ 164,531,531 .^{1}$ There are today thirty-three denominations that are entirely Negro, of which four (the Baptist, African Methodist Episcopal, African Methodist Episcopal Zion, and Colored Methodist Episcopal) are of preponderant importance, since to them belong 83 per cent of all the adult Negro church members in the United States. ${ }^{2}$ The functional importance of the church is so generally understood as to preclude the necessity for protracted exposition. Charles Spurgeon Johnson summarizes the matter:

The church has been and continues to be the outstanding social institution in the $\mathrm{Ne}$ gro community. It has a far wider function than to bring spiritual inspiration to its communicants. The church is still the only institution which provides an effective organization for the group, an approved and tolerated place for social activities, a forum for expression on many issues, an outlet for emotional repressions, and a plan for social living. ${ }^{3}$

Church publications are considerable both in bulk and importance. The oldest Negro periodical in the United States is the weekly Christian Recorder, issued by the African Methodist Episcopal Church, which began publication in 1856 and has continued to the present day. In 1884 this denomination began the publication of a quarterly, the A.M.E. Church Review, which in 1927 was discontinued. This journal is of particular significance as source material on Negro life and history during the period covered, for its pages constituted a forum for expression on politics, prevailing moral and social values, economic problems, race relations, and education, as

1 U.S. Bureau of the Census. Religious Bodies: 1936. Washington, D.C., Government Printing Office, 1941, I, p $73-75$.

3 Johnson, ${ }^{44}$ harles Spurgeon. Growing $U p$ in the Black Belt. Washington, D.C., American Council on Education, 194I, p. 135 . 
well as on religious and denominational matters. It is interesting to find, for example, that certain of the speeches of the Negro abolitionist and reformer, Frederick Douglass, which are not elsewhere recorded, were here printed. The official histories of the various denominations, as well as the journals, are of importance not only as accounts of the establishment and growth of the Negro church, but also as source materials for the history of Negro education.

(2) Fraternal Organizations. There are two types of these organizations, namely the secret and benevolent societies, popularly called "lodges," and the college fraternities and sororities. Like the Negro churches, the "lodges" enlist a large membership and represent a considerable financial investment. Although precise statistics are nowhere available, one student has estimated that the total membership in sixtyodd Negro secret societies is approximately $2,500,000$ and the property they own probably in the neighborhood of $\$ 20,000,000$. Like the churches also, certain of these societies, notably the Odd Fellows, Masons, Knights of Pythias, and the Elks, are imitations of similar white organizations, while other orders are Negro inventions purely. The main, though not the sole, functions of these organizations are social intercourse and the provision of insurance against sickness and death.

Publications of the "lodges" typically include a journal, usually issued monthly; histories of the order; constitutions and bylaws; manuals of ritual and procedure (which are secret and thus not available to libraries); proceedings of the annual conventions; and a large amount of ephemeral material issued in connection with specific, and usually local, activities of the order, such as public programs, mass meetings,

\footnotetext{
4 Ferguson, Charles W. Fifty Million Brothers; $a$ Panorama of American Lodges and Clubs. New York, Farrar and Rinehart, 1937, p. 560.
}

parades, and, interestingly enough, campaign literature related to national, state, and local political elections. These publications are revealing because they disclose the same socio-psychological needs in operation among Negroes as among the white "joiners," and, in addition, because they carry direct expression of the attitudes and opinions of their members on a wide variety of subjects, including politics, labor problems, segregation, housing conditions, and the like.

There are fourteen Greek-letter organizations among Negroes, including undergraduate groups of men and women and honorary and professional fraternities and sororities. The most noteworthy features of these bodies, aside from their social and recreational activities, which follow the general pattern of their white counterparts, has been their voluntary assumption of serious responsibilities to the Negro race. Each offers scholarships to college students, including a few sizable awards for graduate study, and each conducts group projects of various kinds. For example, since 1935 Alpha Kappa Alpha sorority has conducted a mobile health clinic in Mississippi, which has treated thousands of adults for malaria and venereal diseases and immunized more than 14,500 children against diphtheria and smallpox. Thomas Parran, Surgeon General of the United States Public Health Service, calls the clinic's achievement one of the greatest jobs of volunteer public health work he has ever seen. ${ }^{5}$ The quarterly journals issued by each of the Greekletter groups are of interest because they afford direct revelation both of certain aspects of the little-known social life of the college-bred Negro and of his activities in behalf of the Negro group as a whole.

(3) "General" Organizations. The two most important organizations so termed

Satliff, J. D. "Cotton Field Volunteer Clinic." Sur. vey Graphic 29: $464-67,1940$. 
represent large-scale efforts to ameliorate, if not to solve, the "Negro problem" in the United States. The objectives of the National Association for the Advancement of Colored People are the removal of all forms of segregation and racial discrimination against the Negro, and the protection of his civil liberties, through legislative and judicial action. Since the association was founded in 1910 it has won fifteen out of sixteen cases brought before the United States Supreme Court; it renders legal aid (gratis) to Negroes in cases involving civil rights in the lower courts; and is active in lobbying for legislation favorable to $\mathrm{Ne}$ groes, before both Congress and the state legislatures.

The official organ of the association is The Crisis, a monthly journal which began publication in November 1910. In addition to recording the work of the association, The Crisis also carries discussion of racial problems, general news, short stories, and poetry. The fact that it is not included in any of the periodical indexes hampers its reference use considerably. Of particular interest to research are the published legal briefs and arguments of counsel and the factual data assembled for the use of lobbyists and legislators in connection with pending legislation. The detailed annual reports of the association, issued since 1910 , are of considerable general interest and reference value.

The second of the "general" organizations is the National Urban League for Social Service among Negroes, which was founded in I9I I specifically to meet the problems growing out of the migration of increasing numbers of rural Southern $\mathrm{Ne}$ groes to the large industrial centers, both North and South. It places its primary emphasis on the development of economic opportunities for Negroes in cities. Through the industrial relations departments of its local branches the league func- tions as a large-scale employment agency. It maintains close relations with employer groups and with labor unions, with social work agencies, and with national, state, and local officials concerned with labor and industry. Vocational education, civic educafion, and workers education are also important league activities.

The official journal of the league, $O p$ portunity, is issued monthly and is indexed in the Public Affairs Information Service. Its contents include articles by officials of the league and by outside specialists, particularly in such fields as industrial trends, labor problems, housing, and race relations; general news, in a section called "Survey of the Month;" and literary contributions. It is interesting to find that its literary material is frequently included in various anthologies. During 1940 the New York Herald Tribune reproduced eight of its poems in issues of its "Week of Verse," and the Best Short Stories of 1940 compiled by E. J. H. O'Brien listed four of its short stories among the "distinctive short stories of the year." The league publishes its Annual Reports and issues as separates certain of the studies of its research department. These last consist chiefly of surveys of Negro populations in cities; studies dealing with industry, migration, race relations, and housing, with particular reference to the Negro; and bibliographies, such as Source Materials on the Urban Negro in the United States, 1910-1938 (1939). The research department prepares in addition the quarterly house organ of the league, The Secretariat, which stresses urban league techniques for handling specific situations. The league from time to time releases pamphlets, some of which are factual, others primarily propagandist in nature, The publications of the National Urban League are, without question, important source materials for the study of Negro life and history in the United States. Its 
fact-finding investigations are scientifically reliable and supply data not elsewhere available on many phases of Negro life. The techniques employed by the league to attain specific objectives are quite frankly recorded in its publications, particularly The Secretariat, and constitute an interesting source for the discovery of the methods used by minority groups to reach desired goals.

(4) Labor Unions. With the exception of two occupational groupings in which Negro workers maintain a virtual monopoly (the railroad porters and dining car waiters), the formation of independent Negro unions has been "a protest against the attitude of white organized labor in the United States toward Negro workers." 6 The publication program of each of the unions typically includes a monthly journal and irregularly issued bulletins on matters of immediate importance, sent out by the national headquarters, and processed ephemeral material issued by the union's locals. While these publications are not of general interest, they constitute primary sources of information on the Negro and the labor movement in the United States.

(5) Educational Associations. These bodies have been formed chiefly because of the need felt by Negro teachers and administrators for some media for discussion of the many special problems connected with Negro education. The publications of these organizations are confined for the most part to proceedings of their conferences and to journals usually issued quarterly. These publications, while not in general of a scholarly type, are of interest chiefly because of the insight they give into the special problems of Negro education, the attitudes of Negro educators toward these problems, and the efforts being made toward their solution.

\footnotetext{
- National Urban League. Negro Membership in American Labor Unions. New York, The League, I930, p. 118.
}

(6) Organizations Devoted to Research and Publication. The most important such body is the Association for the Study of Negro Life and History, organized in 1915 for the following purposes:

to collect sociological and historical data on the Negro, to publish books on Negro life and history, to promote the study of the Negro through clubs and organizations, and to foster harmony between the races by interpreting the one to the other. ${ }^{7}$

The association is supported by memberships of individuals and of organizations and by endowments of $\$ 25,000$ each from the Carnegie Corporation of New York and the Laura Spelman Rockefeller Memorial Foundation. The association publishes a very considerable body of research on many phases of Negro life and history, not only in the United States but also in other parts of the world. Many of its publications are doctoral dissertations prepared at American universities, such as The Negro in Tennessee from I865-1880 by A. A. Taylor, written at Harvard University. In addition to the research studies, which form by far the largest part of its list, the association also publishes books for young people dealing.with Negro life and history. These books are historically reliable but are written with the child's reading level in mind. The association issues two periodicals, the Journal of Negro History, a scholarly quarterly, and the Negro History Bulletin, which appears eight times a year and is especially designed for the use of elementary and high schools. The Journal of Negro History is included in the International Index; the Negro History Bulletin is not covered by any of the commercially published indexes. Each year the association sponsors "Negro History Week," the purpose of which is to stimulate general interest in the study of Negro life and his-

${ }^{7}$ Association for the Study of Negro Life and History. First Annual Report. Washington, D.C., The Association, 1916, p. 1. 
tory, and, in connection with it, issues much of interest was that often the headquarters pamphlet material, pictures of distinguished Negroes, and posters. The association is a reputable research organization, and the various publications issued by it are of apparent interest and value.

\section{Summary and Recommendations}

The answer to the question as to which, if any, of the publications of the national Negro organizations are important as source materials is dependent on what aspect of Negro life or history is to be studied. In all probability no one library would wish to assemble all the publications of all the Negro organizations, but it appears quite evident that certain libraries would want to preserve some of them. Investigation indicated that libraries, even those with extensive Negro collections, have tended in general to neglect to assemble these publications. In many cases, broken files or total lack of holdings were due primarily to the fact that the material was not secured at the time of issuance and was not available when the library subsequently wished to secure it. An incidental finding of the organization itself lacked complete files of its own publications.

It is recommended that librarians, especially those having particular interest in Negro materials, give careful thought to the matter of the publications of the national Negro organizations. These should be surveyed carefully, and definite policies should be formulated, so that the lack of a file of a publication will indicate a decision on the part of the library rather than an oversight. Because the bulk of the material is so vast, it is also recommended that librarians of institutions having important Negro collections form a planning committee and divide the task of assembling such of the publications as it seems worth while to keep, on the basis of the individual library's focus of interest. This has not been done in the past and it appears reasonable to think it would be a useful procedure-one which, in fact, might well be extended to include not only the publications of the national Negro organizations but also materials of all kinds by and about the Negro.

\section{Fellowships and Scholarships at the University of Chicago}

THE Graduate Library School of the University of Chicago has announced three 1 fellowships of \$1200 each for graduate study in librarianship during the 1946-47 academic year and several tuition scholarships for study leading to graduate degrees and to the bachelor of library science degree. These are outright awards, not payment for services to be rendered.

The fellowship grants are available to students in the A.M. and Ph.D. programs. The requirements for advanced study include college graduation, library school education, and library experience. Application for graduate fellowships and scholarships must be made by Mar. 10, 1946 .

The scholarship grants are available (a) to students in the graduate programs, (b) students in the one-year program leading to the B.L.S. degree, who must have four years of college credit, and (c) students in the three-year subject and professional program leading to the B.L.S. degree, who must have two years of college credit. Applications for scholarships in the bachelor of library science courses should be filed by June 15, 1946.

Forms for applying for awards may be obtained by writing to the Dean, Graduate Library School, University of Chicago, Chicago 37. 